\title{
Relational attractiveness between supplier-customer in a supply chain
}

\author{
Rodrigo Soares Santana and
}

Gustavo Hermínio Salati Marcondes de Moraes

Faculdade de Ciências Aplicadas da Universidade Estadual de Campinas (UNICAMP), Limeira, Brazil, and

\begin{abstract}
Purpose - This study aims to evaluate the influence of factors attributed to relationship attractiveness between supplier and customer, from the supplier's perspective.

Design/methodology/approach - The empirical exercise was based on the use of multivariate data analysis with confirmatory factor analysis and a partial least squares approach to structural equation modeling.

Findings - The study resulted in a robust model, with a high explanatory factor for the latent variable relational attractiveness and commitment was the most influential factor, followed by expected value and interorganizational trust.

Research limitations/implications - Some limitations of the study can be highlighted: conducting research in a single cooperative and with a single audience; choosing a short-cycle supply chain, which may make it difficult to generalize to other industries; the cross-section nature of data also hinders the analysis to understand how the association between variables of interest may vary over time.

Practical implications - The negative influence of interpersonal trust reinforces the importance of developing collaborative attitudes between parties, whereas the non-significant value for dependence (financial and volume dependence) shows this is not a risk factor for relational attractiveness in a supply chain. Such results provide evidence on how to develop relationship management between suppliers and customers that are part of the same supply chain.

Social implications - It offers a new perspective for research in cooperatives, which still have no consensus on the motivating factors for members' participation, including as evidence the results of the largest flower producing center in Latin America. The more a cooperative succeeds in increasing relational attractiveness, the greater the cooperative power and the ability to adapt to shocks and changes, which are fundamental factors for the success and longevity of the cooperative.
\end{abstract}

(C) Rodrigo Soares Santana, Gustavo Hermínio Salati Marcondes de Moraes and Hermes Moretti Ribeiro da Silva. Published in RAUSP Management Journal. Published by Emerald Publishing Limited. This article is published under the Creative Commons Attribution (CC BY 4.0) license. Anyone may reproduce, distribute, translate and create derivative works of this article (for both commercial and noncommercial purposes), subject to full attribution to the original publication and authors. The full terms of this license may be seen at http://creativecommons.org/licences/by/4.0/legalcode

The authors thank Espaço da Escrita - Coordenadoria Geral da Universidade - Unicamp - for the language services provided.

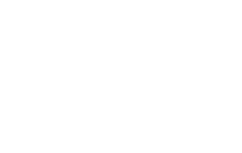


RAUSP

56,1

Originality/value - The research presents a model that is comprehensive enough to fit in different contexts and consider its specific characteristics. Additionally, this paper has added in-depth information on the relational attractiveness relationships in the context of a developing country.

Keywords Brazil, Relationship marketing, B2B relationship, Cooperativism, Relational attractiveness

Paper type Research paper

\section{Introduction}

The ability of managers to handle individual short and long-term network relationships between suppliers and customers determines a company's ability to compete (Palmer, Lindgreen \& Vanhamme, 2005). The integration between parties can bring interesting results for both sides because the better and more aligned this relationship is, the more effective transactions are and the more can be extracted from this business environment. Results can be enhanced when all links of the chain cooperate and share information, planning, goals, strategy and innovations (Cao \& Zhang, 2011; Martins, Faria, Prearo \& Arruda, 2017).

Companies can achieve competitive advantages and superior financial results through trust-based relationship building and management, enabling investment and information exchange (Ashnai, Henneberg, Naudé, \& Francescucci, 2016; Kharouf \& Lund, 2018), incorporating interfirm resources and routines into a critical resource (Dyer \& Singh, 1998).

Relationship marketing is a tool used within the supply chain that is designed to increase stakeholder satisfaction and can be used to create better synergy by gathering information that helps in building demand predictability, understanding consumer behavior, as well as other benefits in the chain that can turn into strategic differentials (Abeza, Finch, O'Reilly, MacIntosh, \& Nadeau, 2019; Kozlenkova, Hult, Lund, Mena, \& Kekec, 2015). In essence, relationship marketing is based on the principle of establishing, maintaining and improving mutually successful relationships, where value is created for all parties (Gummesson, 2017; O’Malley, 2014; Sheth, 2017).

Given that relationship marketing investments can be applied to increase attractiveness in the business chain (Patterson, Johnson, \& Spreng, 1997), the concept of attractiveness can define both the beginning of the relationship and its very development (Harris, O'Malley, \& Patterson, 2003). One must know, which factors influence the attractiveness of the suppliercustomer relationship in a supply chain to set priorities for directing resources and to establish and manage relationships between companies (Pihlajamaa, Kaipia, Aminoff, \& Tanskanen, 2019; Sharma, Kumar, Yan, \& Borah, 2019).

Based on the arguments above, the first academic debate claims more sophisticated investigations about the factors that involve the attractiveness of the supplier-customer relationship in a supply chain (Mortensen, 2012; Tóth, Thiesbrummel, Henneberg, \& Naudé, 2015). The second academic debate requires more research on the effectiveness in managing relationships between companies that are part of the same supply chain (Pihlajamaa et al., 2019; Sharma et al., 2019; Vieira \& Bonifácio-da-Silva, 2016). Inspired by these academic gaps, this article analyzes a recent issue on the subject of business to business and intends to validate a new construct where actionable factors are related to relational attractiveness in a supply chain that has cooperative suppliers as protagonists (flower market in Brazil), allowing to frame the supplier point of view. The focus on a cooperative is especially interesting because in the cooperative logic the articulation takes place with a view to cooperation and sharing of results (Teixeira \& Roglio, 2015). 
A cooperative has as its fundamental hierarchy a general assembly, in which all members are entitled to vote. As the supreme decision-making body, a fiscal council is responsible for the execution of the budget and a board of directors is responsible for controlling the management of the cooperative (Zylbersztajn \& Neves, 2000). Thus, members exercise at the same time the figure of the user, customer, owner and manager. As the board of directors of the cooperative's objectives, management manages the business objectives and is most successful when these objectives are used under the principles and values of cooperation (Novkovic, 2006).

In the context of the agricultural sector, some weaknesses can be found. Often, producers have no professional preparation or maturity to manage or undertake in cooperation; in addition, the fact that there is no division between ownership and control can, among other consequences, lead to problems common to all cooperatives (Sykuta \& Cook, 2001). For this reason, depending on some factors dealt with in specific legislation and always recorded in the statute of each cooperative, the board of directors can count on the support of uncooperative professionals to conduct management (president, executive officers and managers), appointed or contracted and always subordinate to the board of directors (Costa, Chaddad, \& Azevedo, 2012).

It is worth noting that studies on the relationship between the levels of analysis of cooperatives that use adequate data processing are presented as a research gap in this area (Teixeira and Roglio, 2015), especially studies with cooperative members and quantitative indicators (Cavallaro, Furlaneti, \& Krakauer, 2016). There is no consensus in research concerning the main motivators of cooperative members (Morfi, Nilsson, \& Österberg, 2018). While some authors mention that motivation is the result of personal incentives, \& that socially-oriented factors such as traditions and community or status and prestige are less relevant (Morfi et al., 2018), others emphasize that collective incentives are more important (Birchall and Simmons, 2004).

As the success of the cooperative depends, among other factors, on the attitude of cooperation between cooperative members and these can be both individuals and legal entities, it is possible to list the combinations of the relationship dimensions to be observed:

- The relationship between the cooperative company and the cooperative, not only through participation in meetings, but in the day-to-day operation and management of the cooperative enterprise.

- The relationship between the cooperative company and the other companies of the same cooperative, exercising an influence role, forming consensus and opinion.

- The relationship between the cooperative, representing all members and the market (customers).

- The relationship between the cooperative company and the market (customers).

Although these relationships are related to each other as layers, with all influences and dependencies, this last combination will be the focus and object of this study, highlighting the participation of the producer in the market that the cooperative has ahead.

In Brazil, flower production, sale and its distribution chain is under development, \& Holambra, in the state of São Paulo, is the city that hosts the largest flower producing center in Latin America, namely, the Veiling Holambra Cooperative, which houses more than 400 suppliers, intermediates the sale of flowers and assists in distribution (Veiling Holambra Cooperative, 2019). At Veiling Holambra Cooperative, each grower receives a fixed percentage of the total revenue generated by the company and receives a higher percentage of their own individual sales (Oliveira, Pozzebon, \& van Heck, 2007). In the latest survey by 
RAUSP

56,1

\section{2}

the Brazilian Institute of Floriculture, Brazilian floriculture presented an average annual growth of $6.17 \%$, having revenues of more than $\mathrm{R} \$ 5.4 \mathrm{bn}$ in 2014 (Lima et al., 2015).

In the environment of the Veiling Holambra Cooperative, an evolution from a transactional to a long-term relationship is underway in most of the chain, which has been highlighted by the increased participation of regular buyers from the self-service and floriculture segment, through direct intermediation - which involves a direct relationship between producers and customers - or indirectly, through commercial operators offered by the cooperative, as opposed to timely auction sales (approximately 30\% of volume), which was for long the main sales channel (Silva, 2012). In this cooperative, the same customers are served concurrently by the cooperated suppliers, who are producers of different species of flowers and plants. This business role with customer relationships can be delegated to the service provided by the cooperative or producers can even be directly involved, devoting financial, structural and human resources to the development and maintenance of customer relationships. Therefore, if this relationship may be more attractive to one supplier than to another, it is interesting to know, which factors influence this decision more to relate with customers, in addition to contributing to exposing the business network factors that should be highlighted to increase such relational attractiveness.

This research evaluated the influence of factors attributed to the relational attractiveness of the relationship between supplier and customer based on a study with suppliers of the Veiling Holambra Cooperative.

\section{Relational attractiveness}

Attractiveness can be understood as the joint construction that describes the force of mutual interests between two actors, which is determined by the lower of the two levels of attractiveness, defined by the attraction vector of one party to another and perceived from the viewer's perspective (Ellegaard \& Ritter, 2007). Thus, customer attractiveness is, for example, determined by the supplier. Within the context of the business relationship, the concept of attractiveness has been studied in three distinct applications, two of which are explicit in this mutual relationship:

(1) Customer-to-supplier attractiveness.

(2) Supplier-to-customer and managed separately, although they arte strongly correlated (Ellegaard \& Ritter, 2007).

(3) The attractiveness of the relationship developed between customer and supplier (Mortensen, 2012), \& this third field is the appropriate environment for this paper.

For Ellegaard and Ritter (2007), attractiveness can be determined by three main factors, namely, value creation or potential value, interaction process (involving trust and commitment) and emotion, the latter being important because it covers an irrational part of decision-making. Other authors, such as Hald, Cordón, and Vollmann (2009), understand attractiveness as a function of three elements, namely, expected value, trust and dependence, defining the concept as a force that creates willingness in acquisition and exchange and leads the supplier and the customer to a mutually beneficial relationship. Notably, trust appears as an element of attractiveness and not just of the relationship itself, exposing how related these concepts are.

Therefore, measuring, which components interfere with the attractiveness of a partnership can directly impact the whole process of developing a relationship between supplier and customer; at first by stimulating the beginning of a relationship with a new 
partner and, then, by promoting new projects with existing partners (Hüttinger, Schiele, \& Veldman, 2012).

For Harris et al. (2003), attractiveness is a component that initiates, maintains and develops a relationship, a concept based on the foundations of social psychology; thus, they define attractiveness in relationships as the degree of perception that partners have on the partnership's past, present and future as professionally appealing in terms of these relationships' ability to provide superior economic benefits, access to important resources and social compatibility (Harris et al., 2003). This corroborates Möller and Aino (2017) when they state that attractiveness at the beginning of the relationship is based solely on presumed reward, \& the experiences materialized during the evolution of the relationship serve to reinforce perceived attractiveness, increasing the potential for exchange and the momentum for initiatives in future investments and adaptations.

In this context, the attitude wherein the supplier has to maintain, improve or invest in business relationships is called relational attractiveness and derives from attractiveness: while customer attractiveness (perceived by the supplier) concerns the next interaction, relational attractiveness focuses on the attractiveness of the relationship itself (Tóth et al., 2015). This concept is particularly relevant in the context of cooperatives as they are created to improve members' production conditions, increasing their bargaining power and allowing them to benefit from modern value chains (Hao et al., 2018).

In light of this recent concept, dimensions that may influence attractiveness and, consequently, relational attractiveness, will be studied as independent variables.

To direct the measure of relational attractiveness as attitude, the same dimensions of the research by Tóth et al. (2015) were used, namely, perception of profitability or future financial performance (profit margins and financial return from the relationship, be it direct or indirect); intention to strengthen the relationship in the future (invest more time to deepen the relationship); future relationship intensity (referring to the interpersonal relationship between the parties). Using the article by Tóth et al. (2015) as a basis for ours is because of the alignment between their concept and the object of our study, the Veiling Holambra Cooperative, and because they were one of the first to use the term relational attractiveness.

\subsection{Research hypotheses}

2.1.1 Trust. As a subject of social relations, trust has definitions in multiple areas; however, the concept that most closely adheres to the business-to-business (B2B) relationship environment and has been adopted by many authors over time (Morgan \& Hunt, 1994; Zaheer, McEvily, \& Perrone, 1998; Hald et al., 2009; Kang \& Jindal, 2015) is that of Anderson \& Narus (1990), which characterizes trust as relating to the perception of one company to another, namely: "the belief that the other company will perform actions that will result in a positive return for our company, and will not act unexpectedly, bringing negative returns to our company" (Anderson \& Narus, 1990, p. 45).

This understanding was further broadened by authors such as Ganesan and Hess (1997) and Zaheer et al. (1998), who noted an important distinction within the trust, stating that it can be observed on two levels, namely, the first concerns interpersonal relationships, whose development occurs between people in the various possible points of contact between companies, including moral aspects; the second level deals with interorganizational relationship, in which the bases of negotiation are based on both the relationship history and the strategic needs of the companies involved, also characterized in more recent studies (Mouzas, Henneberg, \& Naudé, 2007; Tóth et al., 2015; Ashnai et al., 2016).

Kwon and Suh (2004) researched some factors that influence the development of trust, such as investment in relationship-specific assets, behavioral uncertainty, information 
RAUSP

56,1

sharing, partner reputation, perceived satisfaction and perceived conflict. As these factors are variables that can be modified over time, for any direct or indirect reasons, one can see that trust is not something that is established immediately, nor is it constructed linearly.

Therefore, the evolution of trust is related to the evolution of the relationship. This is in line with the fact that trust in inter-company relationships is the basis for several positive effects, among which: value creation through information sharing (Kwon \& Suh, 2005); reduced transaction costs (Zaheer et al., 1998); cooperative behavior and partnership development (Humphreys, Matthews, \& Kumaraswamy, 2003); relationship development and maintenance (Aurier \& N'Goala, 2009); superior financial results \& competitive advantage (Ashnai et al., 2016).

For the purposes of this study, a context in which trust is the result of a genuine interest of joint gain among companies was also explored (Doney \& Cannon, 1997), and this aspect is present in the link between trust and relationship attractiveness, as evidenced in the studies by Mortensen (2012) and Tanskanen and Aminoff (2015).

From this concept elaboration, we accepted as hypotheses:

H1. Perceived interpersonal trust positively influences the attractiveness of the supplier-customer relationship.

H2. Perceived interorganizational trust positively influences the attractiveness of the supplier-customer relationship.

2.1.2 Commitment. Commitment in business relationships occurs when the committed party believes that it pays to work to make the relationship perpetuate, even if it involves some sacrifice, as defined by Anderson and Weitz (1992) and Morgan and Hunt (1994). This same definition is found in more recent studies, such as Ganesan and Hess (1997), Kwon and Suh (2005), Ashnai et al. (2016) and Chae, Choi, and Hur (2017).

Commitment between parties is required when one wants to achieve common goals, and it is the basis for a successful implementation of the supply chain; consequently, its lack weakens and makes future transactions vulnerable (Kwon \& Suh, 2005). For applying the concept in the formulation of the hypothesis, a broader view was adopted:

H3. Commitment positively influences the attractiveness of the supplier-customer relationship.

2.1.3 Expected value. The expected value of a relationship, according to Walter, Ritter, and Gemuenden (2001), is the expectation of results of an interaction between multiple benefits and sacrifices, not necessarily just financial ones. In addition, these benefits may result not only from the relationship itself but also from connected relationships in which the focal relationship has an impact. Such observation is in line with Anderson, Hakansson, and Johanson (1994), by asserting there are direct functions - such as profits and sales volume that have an immediate effect, and indirect functions such as the development of innovations or access to new markets and relationships on account of a first relationship (Ellegaard \& Ritter, 2007).

Such expectation, which can be considered potential value creation - more explicitly related to the generation of economic value (volume and profitability), is a fundamental factor for a customer to be elevated to the status of the preferred customer, for example (Hüttinger et al., 2012), regarding the achievement and surpassing of expectations as an element of maintenance and incentive for new developments, interrelating the concept of expected value to relational attractiveness. 
Expectation can also be seen from both a customer and supplier perspective, having distinct and interesting elements for each part. This statement is presented in the model proposed by Hald et al. (2009): expected value by the buyer may involve cost reduction, reduction in development time and innovation; for the supplier, price and volume are fundamental.

Therefore, reciprocity in the exchange of values is important for parties to make investments in the relationship; this exchange may involve not only the explicit benefit of each party but also consider the opportunity cost of losing a certain customer or the cost of switching suppliers (Tescari \& Brito, 2016).

Thus, for the purpose of evaluating relational attractiveness, the following hypothesis was developed:

H4. Expected value positively influences the attractiveness of the supplier-customer relationship.

2.1.4 Dependence. For Hald et al. (2009), supplier-customer dependence can be considered a complex combination of the expected value of association, association alternates (relating an environment with few supplier or customer options to a high dependency association) and the transaction-specific liability level (also known as exit cost or relationship exchange cost).

This dependency may occur on both sides and the interdependence between them in a bilateral relationship (Tangpong, Michalisin, Traub, \& Melcher, 2015).

The complexity of equilibrium between dependencies is also related to the concept of power, as a condition of dominance can be established on both the supplier and the customer side. Thus, these impacts can bring out opportunistic behaviors so that the dominant party can capture higher financial value from the relationship (Tangpong et al., 2015), which should be considered a risk intrinsic to the business relationship.

Therefore, dependency can be perceived as a threat or just as a normal condition of a strategic relationship, such as in the case of collaborative alliances. Hence, it is convenient to test the hypothesis of negative influence, namely, financial dependence and volume dependence:

H5. The perception of dependency on a relationship negatively influences the attractiveness of the supplier-customer relationship.

\section{Methodological aspects}

The study was developed through quantitative methods using multivariate data analysis. According to the suggestions by (Hair, Hult, Ringle, \& Sarstedt, 2017), in which theories on relational attractiveness in $\mathrm{B} 2 \mathrm{~B}$ are still underdeveloped and the objectives are the prediction and explanation of presented constructs, we opted for using the partial least squares structural equation modeling (PLS-SEM). As the model developed for research has reflective and formative indicators and the sample is small, this is another reason for using PLS-SEM (Chin \& Newsted, 1999; Hair et al., 2017; Hair, Sarstedt, Hopkins, \& Kuppelwieser, 2014).

Based on the theoretical framework, a conceptual integrative model was elaborated to better represent the research objective, which is presented in Figure 1.

The model consists of six constructs and considers five hypotheses around the factors that influence the relational attractiveness between supplier and customer. Relational attractiveness indicators were based on Tóth et al. (2015), whereas interpersonal and interorganizational trust were based on Zaheer et al. (1998); commitment, on Morgan and Hunt (1994); expected value, on 


\section{RAUSP}

56,1

\section{6}

Figure 1.

Conceptual integrative model

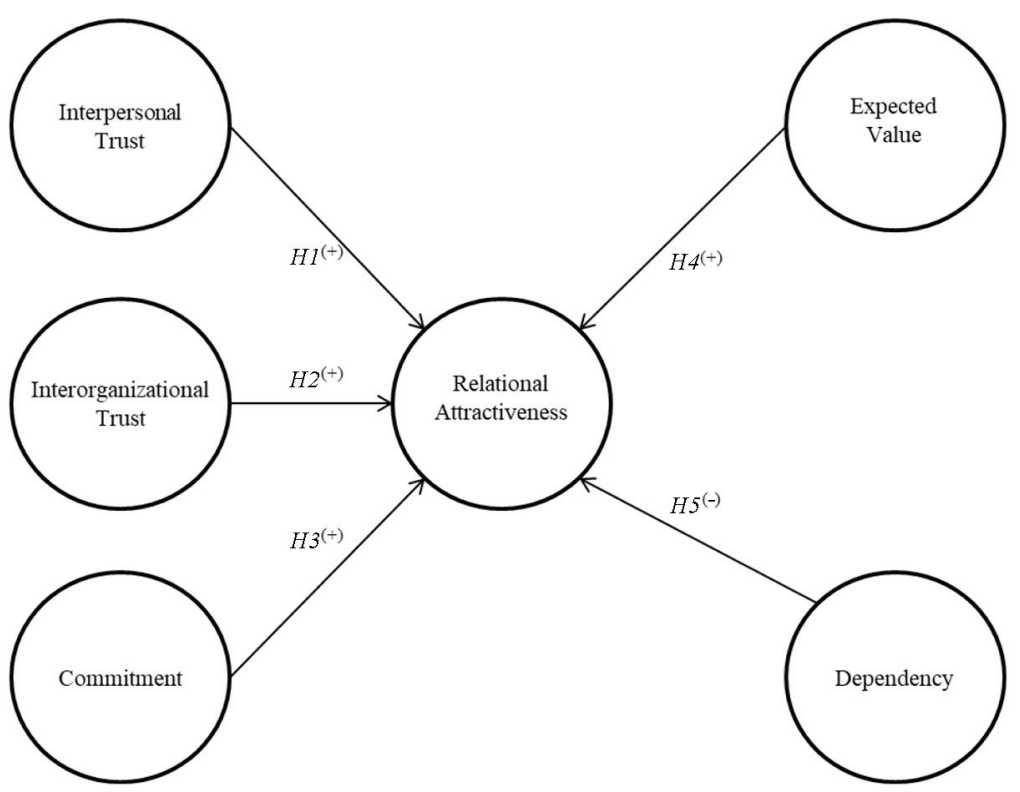

Walter et al. (2001); and dependence, on Schiele and Vos (2015) and Noorderhaven, Nooteboom, and Berger (1998). The choice of these variables is because of the alignment between the authors' concepts and the concept of relational attractiveness chosen for this paper, according to the research objective, which is the Veiling Holambra Cooperative. However, other variables can also influence relational attractiveness.

A single cross-sectional survey was conducted, which, among other objectives, serves to identify opinions of specific groups and the distribution of the phenomenon in the population (Pinsonneault et al., 1993). Data collection was performed using a seven-point Likert-scale structured questionnaire, which was sent to the Research Ethics Committee by submission to Plataforma Brasil. The questionnaire was applied between September and December 2017 through personal interviews, with 118 individuals, all of the producers of the Veiling Holambra Cooperative. All suppliers were contacted; the universe of this sample is represented by about 400 producers registered in the cooperative, our sample being approximately $30 \%$ of the total.

To assess the face validity of the questionnaire, validation was performed with the collaboration of potential respondents to verify their full understanding of the questions. In addition, the questionnaire was screened by specialists for the theories used, relational attractiveness researchers and statisticians to assess the content validity of the assertions (Netemeyer, Bearden, \& Sharma, 2003).

The G*Power 3.1.5 software (Faul, Erdfelder, Buchner, \& Lang, 2009) was used to evaluate the sample size and statistical power of the analyzes, according to recommendations by Chin and Newsted (1999) and Hair et al. (2017). The largest number of arrows that reach a latent variable is 6 (highest number of predictors). Considering six predictors, a significance level of $5 \%$, statistical power of 0.8 and average effect size $\left(f^{2}=\right.$ 0.15 , which is equivalent to $r^{2}=13 \%$ ), the minimum sample size is 98 . As the sample used was 118 respondents, it is adequate for PLS-SEM estimation.

Post hoc analyzes for the obtained sample indicate that: a) any $r^{2}$ greater than $10.88 \%$ would be detected as significant, maintaining the power of 0.8 and significance level at $5 \%$; b) for 
the average effect size, the power is 0.886 , being higher than the value of 0.8 recommended by Chin and Newsted (1999) and Hair et al. (2017).

SmartPLS 3.0M3 software (Ringle, Wende, \& Becker, 2015) was used for statistical test calculations and validations, developed using the multivariate SEM analysis technique.

\section{Description and analysis of results}

A first step in empirical analysis involves the evaluation of measures included in the conceptual model. The measurement instrument was adapted from previous studies. Confirmatory factor analysis (CFA) was used to evaluate the psychometric properties of constructs with SmartPLS 3 (Ringle et al., 2015). All measures were tested in the same model and were restricted to load on their respective factor (Brady \& Cronin, 2001). The CFA results and descriptive statistics are presented in Table 1 . Commitment constructs had no indicator eliminated, while the other constructs had at least one indicator reduced.

Expected value construct was based on Walter et al. (2001) and was measured according to the relationship with cooperative customers (regular volumes already contracted during the year; customers' ability to purchase a large volume if needed; agreement of receiving products that are late or have some minor failure without damaging the relationship; develop new products together; initiate contacts with potential new customers for my company; transmit information about our competitors).

The next step in the analysis is the evaluation of formative measurement models. Criteria for evaluating formative measurement models are, namely, convergent validity, multicollinearity analysis and analysis of the significance and relevance of indicators (Hair et al., 2017). The model has a formative construct, namely, expected value.

Convergent validity was assessed by redundancy analysis. This analysis was made by correlating the variables of the formative construct (expected value) with an overall indicator measure. The construct was modeled with an independent variable, whereas the global measure was modeled with a dependent variable. A recommendation is that the value of the path coefficient must be greater than 0.80 for the construct to present convergent validity (Hair et al., 2017) and the result obtained was 0.817 , considered adequate.

After testing the collinearity of indicators, it was found that all variance inflation factors (variance inflated factor - VIF) of the formative construct had values lower than 5 (Hair et al., 2017).

Significance analysis was obtained using the bootstrapping technique. Initially, the relative importance of each indicator (outer weight) was analyzed. When relative importance is significant, there is empirical support to maintain the indicator (Hair et al., 2017). When relative importance is not significant, it is necessary to evaluate the absolute importance (outer loading) and, if this value is significant, the indicators should be maintained (Hair et al., 2017). According to the results, two indicators had to be eliminated from the expected value formative construct.

Subsequently, the reflexive measurement models were evaluated. Reflective model indicators (relational attractiveness, interpersonal trust, interorganizational trust, commitment and dependence) were assessed by the criteria for evaluating reflexive measurement models, which, according to Hair et al. (2017), are, namely, internal consistency, indicator reliability, convergent validity and discriminant validity.

Discriminant and convergent validity were evaluated at the level of the indicators and latent variables.

Analysis of cross factor loadings showed that most indicators presented high factor loadings in their latent variables, above 0.70 , and low in the other latent variables. However, 


\section{RAUSP \\ 56,1}

118

Table 1.

Standardized CFA path loadings and descriptive statistics

Questions

Standardized

path loading

Critical

ratio

$P$-value $\quad$ Mean

$\mathrm{SD}$

Relational attractiveness

(RA1) We expect to have joint problem-solving activities in the future with our customers (RA2) We would like to deepen the relationship with our customers in the future

$\begin{array}{lrrrr}0.780 & 11.878 & 0.000 & 0.770 & 0.066 \\ 0.801 & 11.149 & 0.000 & 0.789 & 0.072 \\ 0.646 & 6.335 & 0.000 & 0.642 & 0.102 \\ & & & & \\ 0.682 & 6.132 & 0.000 & 0.666 & 0.111 \\ & & & & \\ 0.684 & 3.132 & 0.000 & 0.651 & 0.118 \\ 0.877 & 8.935 & 0.000 & 0.860 & 0.098 \\ 0.520 & 2.198 & 0.000 & 0.759 & 0.144 \\ 0.918 & 11.235 & 0.000 & 0.450 & 0.121\end{array}$

(RA3) We intend to devote more time to our customers if they need more help in the future (RA4) We intend to be prepared or make investments to dedicate special attention to customers who need it, in the future

\section{Interorganizational trust}

(IOT1) The companies we do business with are reliable

(IOT2) Based on past experience, client

companies deliver what they promise

\section{Interpersonal trust}

(IPT1) Most contact persons are reliable

(IPT2) In most cases, we already know how the customer contact person will behave

Commitment

(CM1) Our company is committed to our main customers

(CM2) Even if this brings some loss or additional

effort, we are dedicated to strengthening

relationships with our customers

(CM3) We intend to maintain long-lasting

relationships with our customers

$\begin{array}{lrrrr}0.828 & 10.045 & 0.000 & 0.815 & 0.082 \\ 0.570 & 3.006 & 0.000 & 0.555 & 0.190 \\ 0.839 & 14.420 & 0.000 & 0.839 & 0.058\end{array}$

Dependency

(DP1) If the company lost its main customers it would be difficult to maintain the current level of sales

(DP2) Our customers would find it challenging to find other supplier like our company (DP3) Our company has a high degree of dependence on the main customers in the cooperative

$\begin{array}{lllll}0.628 & 2.121 & 0.000 & 0.510 & 0.151 \\ 0.872 & 2.876 & 0.000 & 0.665 & 0.180 \\ & & & & \\ 0.702 & 2.293 & 0.000 & 0.586 & 0.190\end{array}$

Notes: Questions based on Tóth et al. (2015): RA1, RA2, RA3 and RA4; questions based on Zaheer et al. (1998): IOT1, IOT2, IPT1 and IPT2; questions based on Morgan and Hunt (1994): CM1, CM2 and CM3; questions based on Noorderhaven et al. (1998) and Schiele and Vos (2015): DP1, DP2, DP3

some indicators showed values below 0.70 in their latent variables. According to the suggestions of Hair et al. (2017), Cronbach's composite reliability and alpha indicators of the constructs were analyzed. As some indicators had already been excluded in the CFA, no new indicators had to be excluded.

Another indicator used for convergent validation of the model is the value of the average variance extracted (AVE), which, as a criterion for validation, should have a value greater than 0.5 (Hair, Ringle, \& Sarstedt, 2011). 
To evaluate the measurement model, a main measure used, in addition to examining the loads for each indicator, is the composite reliability of each construct (Hair, Anderson, Tatham, \& Black, 2005; Hair et al., 2017). Composite reliability describes the degree to which indicators represent the common latent construct. A commonly used reference value for acceptable reliability is 0.70 .

Table 2 presents the indicators mentioned and the correlation between the latent variables, as well as the square root of the AVE (bold diagonal). All values are within that established by the authors.

After analysis of the measurement model, we started to analyze the structural model. Criteria used to evaluate the structural model were: collinearity, significant factor loadings, structural coefficients and coefficient of determination of the model $\left(r^{2}\right)$.

To evaluate collinearity, the values of VIF for each subpart of the structural model were analyzed. All values are within the range established by Hair et al. (2017), being below 5 . Values of significant factor loadings and the structural coefficients were obtained by the bootstrapping technique. For this, the student's $t$-statistical analyzes the hypothesis that the significance of path coefficients is equal to zero. $T$-values higher than 1.96 were achieved at a significance level of $5 \%$, rejecting the hypothesis and indicating the path coefficients are significant (Efron and Tibshirani, 1998; Hair et al., 2017). Table 3 presents the $T$-values for the relationship in the model.

All relationship values that presented student's $t$-values greater than 1.96 (significance level $=5 \%$ ) are supported by the corresponding hypothesis. However, some values presented student's T lower than 1.96, not supporting these relationship hypotheses.

According to Table 3, the only relationship that did not show significance was dependency with Attractiveness. On the other hand, the relationship between interpersonal confidence and attractiveness, despite being significant, has a negative influence instead of a positive, as predicted in $H 1$.

To evaluate the coefficient of determination $\left(r^{2}\right)$, the studies by Cohen (1988) and Faul, Erdfelder, Lang, and Buchner (2007) were used, which determine that $f^{2}$ values of $0.02,0.15$ and 0.35 are considered small, medium and large effects, respectively. These $\mathrm{f}^{2}$ values represent $r^{2}$ values equal to $2 \%, 13 \%$ and $25 \%$, respectively.

\begin{tabular}{|c|c|c|c|c|c|c|c|}
\hline Constructs & RA & TIO & IPT & $\mathrm{CM}$ & $\mathrm{EV}$ & DP & \\
\hline Relational attractiveness (RA) & 0.73 & & & & & & \\
\hline Interorganizational trust (IOT) & 0.292 & 0.789 & & & & & \\
\hline Interpersonal trust (IPT) & 0.154 & 0.049 & 0.746 & & & & \\
\hline Commitment (CM) & 0.401 & 0.223 & 0.039 & 0.752 & & & \\
\hline Expected value (EV) & 0.273 & 0.024 & 0.051 & 0.048 & Formative & & Table 2. \\
\hline Dependency (DP) & 0.133 & 0.064 & 0.040 & 0.178 & 0.021 & 0.695 & Summary of the \\
\hline Composite reliability & 0.820 & 0.766 & 0.700 & 0.785 & Formative & 0.733 & evaluation of \\
\hline Average variance extracted (AVE) & 0.535 & 0.622 & 0.557 & 0.565 & Formative & 0.499 & measurement models \\
\hline
\end{tabular}

\begin{tabular}{lcccrr}
\hline Path & Sample mean & SD & T-statistics & $P$-values \\
\cline { 1 - 2 } Interorganizational trust $\rightarrow$ relational attractiveness & 0.237 & 0.104 & 2.186 & 0.029 \\
Interpersonal trust $\rightarrow$ relational attractiveness & -0.166 & 0.083 & 2.034 & 0.042 & Table 3. \\
Commitment $\rightarrow$ relational attractiveness & 0.325 & 0.073 & 4.519 & 0.000 & Coefficients of the \\
Expected value $\rightarrow$ relational attractiveness & 0.251 & 0.087 & 2.767 & 0.006 & structural model - \\
Dependency $\rightarrow$ relational attractiveness & 0.113 & 0.101 & 0.899 & 0.369 & between constructs \\
\cline { 1 - 2 }
\end{tabular}


RAUSP

56,1

According to the analyzes, the relational attractiveness construct presented an $r^{2}$ of 0.303 , considered high. The adjusted model resulting from the research is presented in Figure 2.

In addition to evaluating the magnitude of $r^{2}$ values as a predictive precision criterion, the $Q^{2}$ value, which is an indicator of predictive relevance of the model, was evaluated. The $Q^{2}$ measure applies an example reuse technique that omits part of the data matrix and uses model estimates to predict the omitted part. Specifically, when a PLS-SEM model has predictive relevance, it accurately predicts indicator data points in reflective measurement models. Table 4 shows the values of $r^{2}$, adjusted $r^{2}$ and $Q^{2}$.

For SEM models, $Q^{2}$ values greater than zero for a specific reflective endogenous latent variable indicate the predictive relevance of the path model. In the case of this study, the value is greater than zero.

With the validations obtained with the structural model, we obtained the synthesis of the hypothesis tests of the study (Table 5).

\section{Discussion}

Regarding the study results, relational attractiveness is positively influenced by commitment, interorganizational trust and expected value, confirming studies previously conducted by Hald et al. (2009) and Ellegaard and Ritter (2007). Commitment is the construct

Figure 2.

Complete empirical model

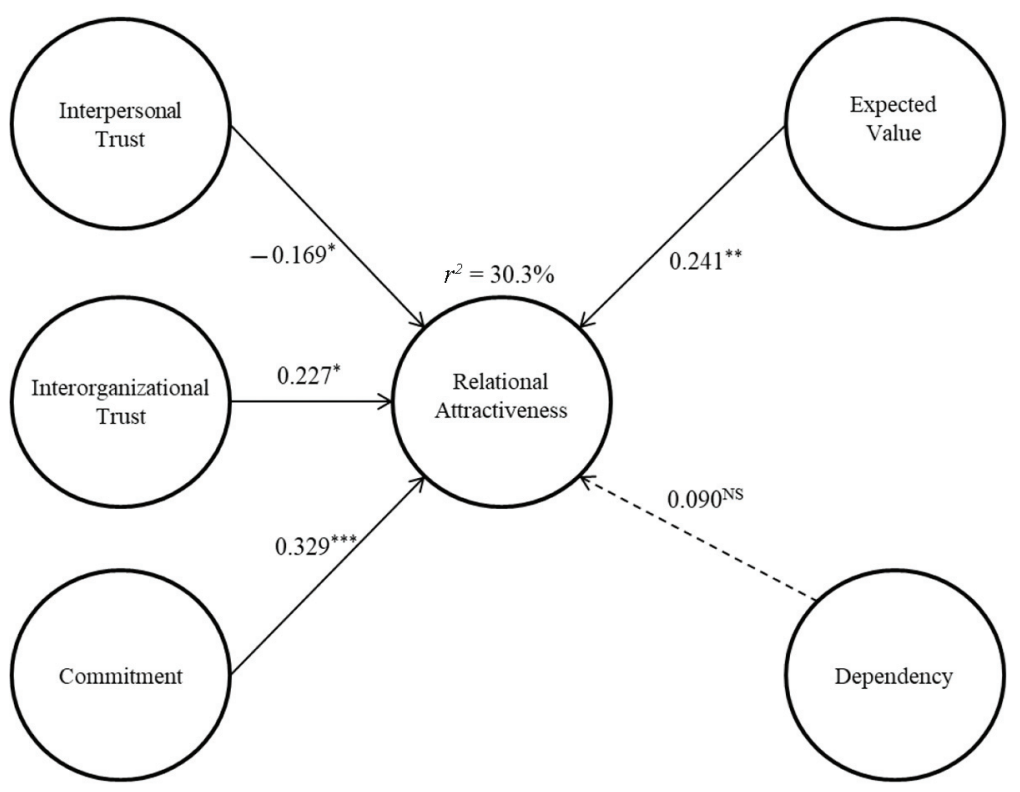

Notes: $*$ significant at $5 \% ; * *$ significant at $1 \% ; * * *=$ significant at $0.1 \% ; \mathrm{NS}=$ not significant

Table 4.

Results of $R^{2}$, adjusted $R^{2}$ and $Q^{2}$ values

\begin{tabular}{lccc}
\hline Construct & $R^{2}$ & Adjusted $R^{2}$ & $Q^{2}$ \\
\hline Relational attractiveness & 0.303 & 0.271 & 0.102 \\
\hline
\end{tabular}




\begin{tabular}{|c|c|c|c|}
\hline Hypothesis & Description & Result & \\
\hline$H 1$ & $\begin{array}{l}\text { Perceived interpersonal trust positively influences the attractiveness of } \\
\text { the supplier-customer relationship }\end{array}$ & Not confirmed & \\
\hline$H 2$ & $\begin{array}{l}\text { Perceived interorganizational trust positively influences the } \\
\text { attractiveness of the supplier-customer relationship }\end{array}$ & Confirmed & \\
\hline H3 & $\begin{array}{l}\text { Commitment positively influences the attractiveness of the supplier- } \\
\text { customer relationship }\end{array}$ & Confirmed & 121 \\
\hline$H 4$ & $\begin{array}{l}\text { Expected value positively influences the attractiveness of the supplier- } \\
\text { customer relationship }\end{array}$ & Confirmed & Table 5. \\
\hline H5 & $\begin{array}{l}\text { The perception of dependence on a relationship negatively influences } \\
\text { the attractiveness of the supplier-customer relationship }\end{array}$ & Not confirmed & $\begin{array}{l}\text { Summary of study } \\
\text { hypotheses testing }\end{array}$ \\
\hline
\end{tabular}

that most influences relational attractiveness. Thus, the greater the desire to establish a stable relationship, even if it involves short-term sacrifices, the greater the perceived attractiveness in the relationship between supplier and customer. The second most influential construct is expected value. Thus, the greater the ratio of perceived benefits to the future expectation of this relationship, the greater the attractiveness. Third is interorganizational trust, indicating that the supplier's belief that the customer will not act negatively toward their company positively influences relational attractiveness.

The concept of relational attractiveness validated in this paper from the perspective of the producer associated with the Veiling Holambra Cooperative demonstrates their interest in not disappointing the customer, reflected in high explanatory power of commitment, in addition to the perception of value and expectations of the future, mainly because of the constant buying behavior of regular customers. In addition, the high commitment observed can be influenced or moderated by another strong relationship that exists between the cooperative company and the whole cooperative, wherein every singular contact along with customer and the cooperative company contributes to shape the customer perception of the whole cooperative at all, where every cooperative company is responsible and benefited at the same time.

However, the active attitude of the cooperative company in approaching, relating and getting to know the characteristics and needs of customers and intermediaries is still restricted to a few producers who are inclined to this task, perhaps, because of the matter of opportunity costs related to arising from the complex and specific activities of their primary activities mentioned in Zylbersztajn (1994). Another variable that can be attributed to the cooperative's decision to improve the relationship with the customer and take on commercial activities with autonomy is the size of the business. There is a wide variety of profiles at Cooperativa Veiling Holambra: from a simple producer, where the question of opportunity costs to multiple functions is fully applicable, to a well-established company, where that simple producer is replaced by a businessman who uses resources human beings to play auxiliary roles in the management of the company, including professional salespeople to exercise the commercial function. Therefore, the variable company size should be considered as a potential moderating factor.

The results obtained corroborate Birchall and Simmons (2004), where collective incentives are the main motivation mechanisms for participation in cooperatives. However, the results are opposite to those of Morfi et al. (2018), who show that members of cooperatives are interested in personal advantages and incentives. The differences in research findings in cooperatives may be due to the conception of members of a cooperative. 
RAUSP

56,1

While some cooperatives are business-oriented, with the members' shares being tradable on the market, harsh market conditions encourage them to continue in the cooperative, but creating a more individualistic posture (Morfi et al., 2018). Other cooperatives, such as Veiling Holambra, are more focused on the common good of the members, increasing their bargaining power and allowing them to benefit from modern value chains (Hao et al., 2018).

To understand the factors that could generate better performance in the establishment and development of the relationship between supplier and customer in the context of the Veiling Holambra Cooperative, the non-acceptance of the $H 1$ (interpersonal trust) and $H 5$ (dependency) hypotheses must be observed in view of the cooperative's operational context, as some features may be unique to this environment:

- Every sale is made with cash payment or with a short payment term, with the cooperative having the role of guarantor of payment to the producer within a maximum of one week after the sale, regardless of the customer, eliminating the risk of loss of revenue.

- The customer has up to three days to claim a return for quality problems, with a guaranteed refund provided if the problem is proven.

- Usually, a product has more than one supplier and there is no restriction on the variety of products that a producer can supply.

- Seasonality applies both to demand (Mother's Day, Day of the Dead, etc.) and to supply (species with cold weather in winter).

Therefore, there is a competitive model where the default risk has been mitigated, and market behavior (demanded or offered) can vary according to the type or time. Thus, the producer can choose with whom they will establish a deeper relationship, identify, which would be the best partners, and develop and nurture a portfolio of relationships, and this choice must be oriented to obtain a competitive advantage, superior financial performance, at the same time that the customer may be exposed to opportunistic behavior by the supplier (producer can take advantage to charge more in seasonality). Hence, the rejection of H5 (dependency) in this environment.

When there is, on the part of the flower customer, a low dependence on the supplier and there is more than one producer supplying the same product with the same quality standard or when the customer needs a specific item and depends on the supplier for that or when the supply of flowers is missing by some precedent, the entire market becomes competitive and players can perform transactional behavior.

It is important to consider that the supplier knows most customers through contact with the same people over the years, including their predictable behavior. However, producers clearly evaluated during the interviews that, if the customers have the opportunity, they will act negatively with respect to the company, a fact supported by the theory of opportunistic behaviors in the absence of interpersonal trust (Morgan \& Hunt, 1994), which leads to the rejection of $H 1$ (interpersonal trust).

\section{Conclusion}

This study evaluated the influence of factors attributed to the attractiveness of the relationship between supplier and customer, through a study with suppliers belonging to a cooperative located in the largest flower producing center in Latin America. As a result, we obtained a robust model with a high explanatory value for the latent variable of relational attractiveness. It also offers a new perspective for research in cooperatives, which still have no consensus on the motivating factors for members' participation 
(Morfi et al., 2018), including as evidence the results of the largest flower producing center in Latin America. The more a cooperative succeeds in increasing relational attractiveness, the greater the cooperative power and the ability to adapt to shocks and changes, which are fundamental factors for the success and longevity of the cooperative (Iliopoulos \& Valentinov, 2018).

Based on the results obtained from the information provided by the Veiling Holambra Cooperative supplier, the importance of developing collaborative attitudes between suppliercustomer contact people to increase interpersonal trust is evident. According to the literature and the proposed model, trust is one of the factors that highlight relational attractiveness; Therefore, this functions as an opportunity to intensify existing relationships, aiming for strategic partnerships and collaboration between supplier and customer, mainly through the development of the trust that the supplier places on the customer, both interpersonal and interorganizational.

One way to work on this approach is through adaptations in the sales process; however, it is more difficult to understand this process and make changes when the client adopts transactional behavior (Viio \& Grónroos, 2016). These changes can serve to expand communication and exchange information, reducing uncertainties to improve the development of trust (Williamson, 1985; Kwon \& Suh, 2004).

It was observed in the case study presented by Viio and Grónroos (2016) that, when the supplier adapted their sales process to facilitate the connection with the buyer's purchase process, he supported him in the activity. The study suggests an overlap between knowledge of the customer's purchasing process \& the supplier's intention to adapt their sales process to lead to a value-based commitment in the business relationship.

In addition, taking advantage of the moment of approximation to build relational value as proposed by Pardo, Henneberg, Mouzas, and Naudé (2005) through the sharing of needs and the co-creation of supply can also lead to a reduction in opportunistic behavior in the face of a better perception of value captured in the relationship with the customer.

Some limitations of the study can be highlighted: conducting research in a single cooperative and with a single audience; choosing a short-cycle supply chain, which may make it difficult to generalize to other industries; the cross-sectional nature of data also hinders our analysis to verify how the association between variables of interest may vary over time. The number of cooperative producers disclosed by Cooperativa Veiling Holambra is composed of registered producers, and the same company has more than one registered cooperative member (often composed of members of the same family), otherwise the cooperative registration is in the name of a producer who does not perform the function anymore, which resulted in the practical reduction of the researched universe and the low significance of some variables. This wide range of companies profiles should influence, in some aspect, the relational attractiveness, where small producers are more affected by opportunity costs and could be forced to focus in primary activities of production (Zylbersztajn, 1994) and delegates sales activities to the cooperative sales department and auction channel, opposing to bigger producers that have more financial resources to invest in management assistance, including hire salespersons to be in charge of all commercial issues and customer relationship. This should evidence "company size" as a factor that moderates relational attractiveness.

As suggestions for further research, we recommend: applying the same model in other industries and comparing the results to collaborate with the consolidation of the relational attractiveness construct, so that it becomes an approach tool in the field of relationship marketing; develop longitudinal studies, capturing how variables of interest and relationships may vary over time; research different audiences in the same supply 
RAUSP

56,1

chain to minimize the perception bias of a specific audience. Another approach might consider that, perhaps, the interference of other variables related to market behavior - be it demanded or offered, due to the scarcity of species or seasonality - could be studied including these factors as moderators or variables with a direct relation to relational attractiveness.

Another factor that could have been highlighted is opportunism (Zhou, Zhang, Zhuang, and Zhou, 2015), due to the precedents of opportunism regarding incongruity of goals, sense of injustice, termination costs and conflicts (Kang \& Jindal, 2015), in addition to better exploring the relationship of power and dependency on the part of the client (Tangpong et al., 2015). It would be interesting to see how the opportunism present in a relationship interferes with the perception of its attractiveness.

Despite the presented limitations, the research contribution brings to light relevant aspects for this promising research field.

\section{References}

Abeza, G., Finch, D., O’Reilly, N., MacIntosh, E., \& Nadeau, J. (2019). An integrative model of sport relationship marketing: transforming insights into action. Journal of Sport Management, 33(4), 343-360. https://doi.org/10.1123/jsm.2018-0285

Anderson, E., \& Weitz, B. (1992). The use of pledges to build and sustain commitment in distribution channels. Journal of Marketing Research, 29(1), 18. https://doi.org/10.2307/3172490

Anderson, J. C., \& Narus, J. A. (1990). A model of distributor firm and manufacturer firm working partnerships. Journal of Marketing, 54(1), 42-58. https://doi.org/10.2307/1252172

Anderson, J. C., Hakansson, H., \& Johanson, J. (1994). Dyadic business relationships withing a business network context. Journal of Marketing, 58(4), 1. https://doi.org/10.1177/002224299405800401

Ashnai, B., Henneberg, S. C., Naudé, P., \& Francescucci, A. (2016). Inter-personal and interorganizational trust in business relationships: An attitude-behavior-outcome model. Industrial Marketing Management, 52, 128-139. https://doi.org/10.1016/j.indmarman.2015.05.020

Aurier, P., \& N'Goala, G. (2009). The differing and mediating roles of trust and relationship commitment in service relationship maintenance and development. Journal of the Academy of Marketing Science, 38(3), 303-325. https://doi.org/10.1007/s11747-009-0163-z

Birchall, J., \& Simmons, R. (2004). What motivates members to participate inco-operative and mutual businesses? A theoretical model and some findings. Annals of Public and Cooperative Economics, 75(3), 465-495. https://doi.org/10.1111/j.1467-8292.2004.00259.x

Brady, M. K., \& Cronin, J. J. (2001). Some new thoughts on conceptualizing perceived service quality: A hierarchical approach. Journal of Marketing, 65(3), 34-49. https://doi.org/10.1509/ jmkg.65.3.34.18334

Cao, M., \& Zhang, Q. (2011). Supply chain collaboration: Impact on collaborative advantage and firm performance. Journal of Operations Management, 29(3), 163-180. https://doi.org/10.1016/j. jom.2010.12.008

Cavallaro, G. M., Furlaneti, E. W., \& Krakauer, P. V. C. (2016). Cluster e desenvolvimento local: O caso da cooperativa veiling holambra. Revista ESPACIOS, 37, 19.

Chae, S., Choi, T. Y., \& Hur, D. (2017). Buyer power and supplier relationship commitment: A cognitive evaluation theory perspective. Journal of Supply Chain Management, 53(2), 39-60. https://doi. org $/ 10.1111 /$ jscm. 12138

Chin, W. W., \& Newsted, P. R. (1999). Structural equation modeling analysis with small samples using partial least squares. Statistical Strategies for Small Sample Research, 1, 307-341.

Cohen, J. (1988). Statistical power analysis for the behavioral sciences, 2nd edn. Hillsdale: Erlbaum Associates. 
Costa, D. R. D M., Chaddad, F. R., \& Azevedo, P. F. D. (2012). Separação entre propriedade e decisão de gestão nas cooperativas agropecuárias brasileiras. Revista de Economia e Sociologia Rural, 50(2), 285-300. https://doi.org/10.1590/S0103-20032012000200005

Doney, P. M., \& Cannon, J. P. (1997). An examination of the nature of trust in buyer-seller relationships. Journal of Marketing, 61(2), 35-51. https://doi.org/10.2307/1251829

Dyer, J., \& Singh, H. (1998). The relational view: Cooperative strategy and sources of interorganizational competitive advantage. The Academy of Management Review, 23(4). https:// doi.org/10.2307/259056

Efron, B., \& Tibshirani, R. J. (1998). An introduction to the bootstrap, CRC Press.

Ellegaard, C., \& Ritter, T. (2007). Attractiveness in business markets: Conceptualization and propositions. 10. Fonte. Retrieved from http://impgroup.org/paperview.php?viewPaper=5847

Faul, F., Erdfelder, E., Buchner, A., \& Lang, A.-G. (2009). Statistical power analyses using G* power 3.1: Tests for correlation and regression analyses. Behavior Research Methods, 41(4), 1149-1160. https://doi.org/10.3758/BRM.41.4.1149

Faul, F., Erdfelder, E., Lang, A.-G., \& Buchner, A. (2007). G*power 3: A flexible statistical power analysis program for the social, behavioral, and biomedical sciences. Behavior Research Methods, 39(2), 175-191. https://doi.org/10.3758/BF03193146

Ganesan, S., \& Hess, R. (1997). Dimensions and levels of trust: Implications for commitment to a. Marketing Letters, 8(4), 439-448. https://doi.org/10.1023/A:1007955514781

Gummesson, E. (2017). From relationship marketing to total relationship marketing and beyond. Journal of Services Marketing, 31(1), 16-19. https://doi.org/10.1108/JSM-11-2016-0398

Hair, J. F., Jr, Anderson, R. E., Tatham, R. L., \& Black, W. C. (2005). Análise multivariada de dados. Tradução: Adonai schlup sant'Anna e anselmo chaves neto, Porto Alegre: Bookman.

Hair, J. F., Jr, Ringle, C. M., \& Sarstedt, M. (2011). PLS-SEM: Indeed a silver bullet. Journal of Marketing Theory and Practice, 19(2), 139-152. https://doi.org/10.2753/MTP10696679190202

Hair, J. F., Jr, Sarstedt, M., Hopkins, L., \& Kuppelwieser, V. G. (2014). Partial least squares structural equation modeling (PLS-SEM): An emerging tool in business research. European Business Review, 26(2), 106-121. https://doi.org/10.1108/EBR-10-2013-0128

Hair, J. F., Jr, Hult, G. M., Ringle, C., \& Sarstedt, M. (2017). A primer on partial least squares structural equation modeling (PLS-SEM, Thousand Oaks, CA: SAGE Publications.

Hald, K. S., Cordón, C., \& Vollmann, T. E. (2009). Towards an understanding of attraction in buyersupplier relationships. Industrial Marketing Management, 38(8), 960-970. https://doi.org/ 10.1016/j.indmarman.2008.04.015

Hao, J., Bijman, J., Gardebroek, C., Heerink, N., Heijman, W., \& Huo, X. (2018). Cooperative membership and farmers' choice of marketing channels - Evidence from apple farmers in Shaanxi and Shandong provinces. Food Policy, 74, 53-64. https://doi.org/10.1016/j. foodpol.2017.11.004

Harris, L. C., O’Malley, L., \& Patterson, M. (2003). Professional interaction: Exploring the concept of attraction. Marketing Theory, 3(1), 9-36. https://doi.org/10.1177/1470593103003001002

Humphreys, P., Matthews, J., \& Kumaraswamy, M. (2003). Pre-construction project partnering: From adversarial to collaborative relationships. Supply Chain Management: An International Journal, 8(2), 166-178. https://doi.org/10.1108/13598540310468760

Hüttinger, L., Schiele, H., \& Veldman, J. (2012). The drivers of customer attractiveness, supplier satisfaction and preferred customer status: A literature review. Industrial Marketing Management, 41(8), 1194-1205. https://doi.org/10.1016/j.indmarman.2012.10.004

Iliopoulos, C., \& Valentinov, V. (2018). Cooperative longevity: Why are so many cooperatives so successful? Sustainability, 10(10), 1-8. https://doi.org/10.3390/su10103449 
RAUSP

56,1

Kang, B., \& Jindal, R. P. (2015). Opportunism in buyer-seller relationships: Some unexplored antecedents. Journal of Business Research, 68(3), 735-742. https://doi.org/10.1016/j. jbusres.2014.07.009

Kharouf, H., \& Lund, D. J. (2018). An empirical examination of organisational trust recovery: Influences and implications. European Management Review, 16(4). https://doi.org/10.1111/emre.12309

Kozlenkova, I. V., Hult, G. T., Lund, D. J., Mena, J. A., \& Kekec, P. (2015). The role of marketing channels in supply chain management. Journal of Retailing, 91(4), 586-609. https://doi.org/10.1016/j. jretai.2015.03.003

Kwon, I.-W. G., \& Suh, T. (2004). Factors affecting the level of trust and commitment in supply chain relationships. The Journal of Supply Chain Management, 40(2), 4-14. https://doi.org/10.1111/ j.1745-493X.2004.tb00165.x

Kwon, I.-W. G., \& Suh, T. (2005). Trust, commitment and relationships in supply chain management: A path analysis. Supply Chain Management: An International Journal, 10(1), 26-33. https://doi.org/ 10.1108/13598540510578351

Lima, J. C., Jr, Nakatani, J. K., Neto, L. C., Lima, L. A., Kalaki, R. B., \& Camargo, R. B. (2015). Mapeamento e quantificação da cadeia de flores e plantas ornamentais do Brasil. In M. F. Neves, \& M. J. Alves Pinto, (Eds), Organização das cooperativas do estado de são paulo, (Vol. 53), São Paulo: OCESP.

Martins, D., Faria, A. C., Prearo, L., \& Arruda, A. (2017). The level of influence of trust, commitment, cooperation, and power in the interorganizational relationships of Brazilian credit cooperatives. Revista de Administração, 52(1), 47-58. https://doi.org/10.1016/j.rausp.2016.09.003

Möller, K., \& Aino, H. (2017). Managing business and innovation networks - from strategic nets to business fields and ecosystems. Industrial Marketing Management, 67. https://doi.org/10.1016/j. indmarman.2017.09.018

Morfi, C., Nilsson, J., \& Österberg, H. (2018). Why farmers involve themselves in cooperative district councils. Annals of Public and Cooperative Economics, 89(4), 581-598. https://doi.org/10.1111/ apce. 12206

Morgan, R. M., \& Hunt, S. D. (1994). Theory of relationship marketing. Journal of Marketing, 58(3), 20-38. https://doi.org/10.1177/002224299405800302

Mortensen, M. H. (2012). Understanding attractiveness in business relationships - A complete literature review. Industrial Marketing Management, 41(8), 1206-1218. https://doi.org/10.1016/j. indmarman.2012.10.005

Mouzas, S., Henneberg, S., \& Naudé, P. (2007). Trust and reliance in business relationships. European Journal of Marketing, 41(9-10), 1016-1032. https://doi.org/10.1108/03090560710773327

Netemeyer, R. G., Bearden, W. O., \& Sharma, S. (2003). Scaling procedures: Issues and applications, SAGE Publications.

Noorderhaven, N. G., Nooteboom, B., \& Berger, H. (1998). Determinants of perceived interfirm dependence in industrial supplier relations. Journal of Management \& Governance, 2(3), 213-232. https://doi.org/10.1023/A:1009962926611

Novkovic, S. (2006). Co-operative business: The role of co-operative principles and values. Journal of CoOperative Studies, 39, 5-15.

O'Malley, L. (2014). Relational marketing: Development, debates and directions. Journal of Marketing Management, 30(11-12), 1220-1238. https://doi.org/10.1080/0267257X.2014.939592

Oliveira, R., Pozzebon, M., \& van Heck, E. (2007). Veiling Holambra - Trading Brazilian flowers in the international market enabled by IT. Journal of Information Technology Case and Application Research, 9(1), 38-58. https://doi.org/10.1080/15228053.2007.10856106

Palmer, R., Lindgreen, A., \& Vanhamme, J. (2005). Relationship marketing: Schools of thought and future research directions. Marketing Intelligence \& Planning, 23(3), 313-330. https://doi.org/ $10.1108 / 02634500510597337$ 
Pardo, C., Henneberg, S., Mouzas, S., \& Naudé, P. (2005). Unpicking the meaning of value in key account management. University of Bath, 1, 1-30. https://doi.org/10.1017/CBO9781107415324.004

Patterson, P. G., Johnson, L. W., \& Spreng, R. A. (1997). Modeling the determinants of customer satisfaction for business- to-business professional services. Journal of the Academy of Marketing Science, 25(1), 4-17. https://doi.org/10.1177/0092070397251002

Pihlajamaa, M., Kaipia, R., Aminoff, A., \& Tanskanen, K. (2019). How to stimulate supplier innovation? Insights from a multiple case study. Journal of Purchasing and Supply Management, 25(3), 3. https://doi.org/10.1016/j.pursup.2019.05.001

Pinsonneault, A., Kraemer, K. L., Journal, S., Systems, I., Fall, N., \& Taylor, P. (1993). Survey research methodology in management information systems: An assessment. Journal of Management Information Systems, 10(2), 75-105. https://doi.org/10.1080/07421222.1993.11518001

Ringle, C. M., Wende, S., \& Becker, J.-M. (2015). SmartPLS 3, Bönningstedt.

Schiele, H., \& Vos, F. G. S. (2015). Dependency on suppliers as a peril in the acquisition of innovations? The role of buyer attractiveness in mitigating potential negative dependency effects in buyer-supplier relations. Australasian Marketing Journal, 23(2), 139-147. https://doi.org/10.1016/j.ausmj.2015.04.009

Sharma, A., Kumar, V., Yan, J., \& Borah, A. A. S. B. (2019). Understanding the structural characteristics of a firm's whole buyer-supplier network and its impact on international business performance. Journal of International Business Studies, 50(3), 365-392. https://doi.org/10.1057/s41267-019-00215-x

Sheth, J. (2017). Revitalizing relationship marketing. Journal of Services Marketing, 31(1), 6-10. https:// doi.org/10.1108/JSM-11-2016-0397

Silva, L. C. (2012). Caracterização do setor atacadista de flores e plantas ornamentais no Brasil. Ph.D. dissertation, Universidade Federal de Lavras.

Sykuta, M. E., \& Cook, M. L. (2001). A new institutional economics approach to contracts and cooperatives. American Journal of Agricultural Economics, 83(5), 1273-1279. https://doi.org/ 10.1111/0002-9092.00278

Tangpong, C., Michalisin, M. D., Traub, R. D., \& Melcher, A. J. (2015). A review of buyer-supplier relationship typologies: Progress, problems, and future directions. Journal of Business \& Industrial Marketing, 30(2), 153-170. https://doi.org/10.1108/JBIM-10-2012-0193

Tanskanen, K., \& Aminoff, A. (2015). Buyer and supplier attractiveness in a strategic relationship - A dyadic multiple-case study. Industrial Marketing Management, 50, 128-141. https://doi.org/ 10.1016/j.indmarman.2015.04.011

Teixeira, M. G., \& Roglio, K. D. (2015). The influences of institutional logics dynamics on organizational history: The case of Veiling Holambra cooperative. Brazilian Business Review, 12(1), 1-35. https://doi.org/10.15728/bbr.2015.12.1.1

Tescari, F. C., \& Brito, L. A. L. (2016). Value creation and capture in buyer-supplier relationships: A new perspective. Revista de Administração de Empresas, 56(5), 474-488. https://doi.org/10.1590/ s0034-759020160503

Tóth, Z., Thiesbrummel, C., Henneberg, S. C., \& Naudé, P. (2015). Understanding configurations of relational attractiveness of the customer firm using fuzzy set QCA. Journal of Business Research, 68(3), 723-734. https://doi.org/10.1016/j.jbusres.2014.07.010

Veiling Holambra Cooperative. (2019). Site institucional da cooperativa Veiling Holambra. Retrieved from www.veiling.com.br/

Vieira, V., \& Bonifácio-da-Silva, W. (2016). Uma análise da relação entre laços imersos e inovação do fornecedor no setor de cooperativismo. Revista de Administração, 51(4), 386-396. https://doi.org/ 10.1016/j.rausp.2016.07.003

Viio, P., \& Grónroos, C. (2016). How buyer-seller relationship orientation affects adaptation of sales processes to the buying process. Industrial Marketing Management, 52, 37-46. https://doi.org/ 10.1016/j.indmarman.2015.07.013 
RAUSP

56,1

Walter, A., Ritter, T., \& Gemuenden, H. (2001). Value creation in buyer-seller relationships: Theoretical considerations and empirical results from a supplier's perspective. Industrial Marketing Management, 30(4), 365-377. https://doi.org/10.1016/S0019-8501(01)00156-0

Williamson, O. E. (1985). The economic institutions of capitalism: Firms, markets, relational contracting, Free Press.

Zaheer, A., McEvily, B., \& Perrone, V. (1998). Does trust matter? Exploring the effects of interorganizational and interpersonal trust on performance. Organization Science, 9(2), 141-159. https://doi.org/10.1287/orsc.9.2.141

Zhou, Y., Zhang, X., Zhuang, G., \& Zhou, N. (2015). Relational norms and collaborative activities: Roles in reducing opportunism in marketing channels. Industrial Marketing Management, 46, 147-159. https://doi.org/10.1016/j.indmarman.2015.01.014

Zylbersztajn, D. (1994). Organização de cooperativas: Desafios e tendências. Revista de Administração, $29,23-32$.

Zylbersztajn, D., \& Neves, M. F. (Org.) (2000). Economia e gestão dos negócios agroalimentares, São Paulo: Pioneira.

\section{Corresponding author}

Gustavo Hermínio Salati Marcondes de Moraes can be contacted at: salati@unicamp.br

Associate Editor: Bruno Silvestre

For instructions on how to order reprints of this article, please visit our website: www.emeraldgrouppublishing.com/licensing/reprints.htm

Or contact us for further details: permissions@emeraldinsight.com 